\title{
PEMANFAATAN PERPUSTAKAAN UNDIKSHA DALAM MENUNJANG PEMBELAJARAN MAHASISWA FAKULTAS ILMU PENDIDIKAN
}

\author{
Adrianus I Wayan Ilia Yuda Sukmana \\ Jurusan Teknologi Pendidikan, Universitas Pendidikan Ganesha \\ E-mail: yudasukmanaTP13@gmail.com \\ Ignatius I Wayan Suwatra \\ Jurusan Teknologi Pendidikan, Universitas Pendidikan Ganesha \\ E-mail:wayansuwatra@yahoo.co.id
}

\begin{abstract}
Abstrak
Penelitian ini merupakan penelitian deskriptif yang bertujuan untuk: 1) mendeskripsikan tingkat kunjungan mahasiswa di Fakultas Pendidikan Undiksha ke perpustakaan Undiksha, 2) mendeskripsikan persepsi mahasiswa tentang layanan pustakawan di perpustakaan Undiksha, 3) menggambarkan persepsi mahasiswa tentang kesesuaian antara materi pembelajaran yang ada dalam perpustakaan dan kebutuhan belajar mahasiswa, 4) mendeskripsikan persepsi dosen di Fakultas Pendidikan Undiksha terhadap kesesuaian bahan pembelajaran di perpustakaan Undiksha dengan kebutuhan pembelajaran, 5) mendeskripsikan faktor-faktor yang mendorong dan menghambat mahasiswa dan dosen untuk memanfaatkan Perpustakaan Undiksha. Subjek penelitian ini adalah mahasiswa, dosen dan pustakawan. Mahasiswa dan dosen yang menjadi subjek penelitian ini ditentukan oleh Quota Proportional Random Sampling. Data yang dibutuhkan dikumpulkan dengan menggunakan metode wawancara dan rekaman dokumen yang kemudian diproses secara deskriptif. Hasil dalam penelitian ini menjelaskan tentang persepsi dosen dan mahasiswa tentang kualitas perpustakaan, kualitas pustakawan dan juga sistem pelayanan perpustakaan Undiksha.
\end{abstract}

Kata kunci: perpustakaan, pustakawan, pemanfaatan perpustakaan

\begin{abstract}
This study was descriptive research that aims to: 1) describe the visit rate of student at Faculty of Education Undiksha to Undiksha's library, 2) describe the students' perceptions about librarian services in Undiksha's library, 3) describe students' perceptions about appropriateness between learning materials in library and learning needs, 4) describe the perception of lecturers in Faculty of Education Undiksha againts the suitability of learning materials in Undiksha's library with the learning needs, 5) describe factors that are driving and inhibiting students and lecturers to utilize Undiksha Library. The subjects of this study are students, lecturers and librarians. Students and lecturers who are the subject of this research are determined by Quota Proportional Random Sampling. The required data are collected by using interview method and document recording which then processed descriptively. The results in this study explain about perceptions of lecturers and students about the quality of libraries, Quality of librarian and alsoUndiksha's library service system.
\end{abstract}

Keywords: library, librarian, library utilization

\section{Pendahuluan}

Perpustakaan memiliki peranan penting dalam upaya memajukan pendidikan dan merupakan salah satu sarana untuk mencerdaskan kehidupan bangsa. Terkait dengan itulah Perpustakaan Undiksha hadir dalam upaya meningkatkan mutu pendidikan di Undiksha. Perpustakaan Undiksha adalah salah satu Unit Pelaksana Teknis (UPT) di lingkungan Undiksha yang bersama-sama dengan unit-unit lainnya memfasilitasi pelaksanaan tri darma perguruan tinggi di Undiksha.

Untuk menciptakaan perpustakaan yang baik maka beberapa hal sangatlah perlu diperhatikan. Salah satunya adalah layanan terhadap pemakai. Layanan terhadap pemakai/pengguna perpustakaan merupakan komponen penting dalam pengelolaan perpustakaan untuk memberikan kemudahan kepada pemakai dalam memperoleh informasi yang mereka perlukan. Layanan pemakai memiliki konsep bahwa dengan mengerti dan memenuhi kebutuhan pemakai, perpustakaan dapat meningkatkan kualitas layanannya, permintaan layanan, dan membangun reputasi yang berkontribusi pada penyelenggaran berbagai program perpustakaan. Sebagaimana disampaikan oleh Stoker (1992) layanan perpustakaan perguruan tinggi harus memperhatikan tingkat kemampuan mahasiswa, permintaan dan kebutuhan yang berbeda antara mahasiswa program 
diploma, sarjana dan mahasiswa program pascasarjana. Perpustakaan yang baik adalah perpustakaan yang koleksinya relevan dengan kebutuhan masyarakat yang dilayani

Komponen lain yang penting untuk diperhatikan adalah pustakawan. Pustakawan adalah salah satu komponen dalam penyelenggaraan yang berkewajiban memberikan layanan yang baik, berkualitas, ramah dan profesional. Berbagai tugas dan kegiatan di perpustakaan, harus disertai dengan pelayanan yang menarik sehingga dapat memuaskan pengguna. Sistem layanan yang memadai bagi pengguna merupakan sumbangan yang positif dalam mewujudkan efisiensis dan menimbulkan daya tarik bagi pengguna untuk mengunjungi dan memanfaatkan berbagai sumber yang dimiliki perpustakaan. Selain itu, pustakawan juga harus memberikan bantuan dan bimbingan kepada pemakai yang menemukan kesulitan dalam melakukan penelusuran dan menemukan bahan pustaka yang dibutuhkan.

Di samping sarana dan prasarana dan pustakawan, sistem layanan, pengguna perpustakaan, kelengkapan dan kesesuaian pustaka dengan kebutuhan pengguna, terutama yang terkait dengan kurikulum, merupakan komponen mutlak yang harus ada dalam penyelenggaraan perpustakaan termasuk keberlanjutan dan pengembangannya.Layanan kepada pengguna perpustakaan bisa dilakukan secara terbuka (open acces) dan secara tertutup (closed acces).

Sebagai tempat dan sumber belajar, idealnya perpustakaan bisa dimanfaatkan secara optimal oleh penggunanya minimal oleh mahasiswa dan dosen. Karena itu bahan pustaka seperti buku, kamus, ensiklopedi dan sumber-sumber lainnya harus betul-betul sesuai dengan tuntutan kurikulum/mata kuliah dari masingmasing jurusan. Perpustakaan mesti menyediakan bahan-bahan pustaka terkini sebagai salah satu cara memotivasi pengguna mengunjungi perpustakaan. Pengadaan bahan pustaka mesti memperhatikan masukan dari pihak dosen sesuai mata kuliah yang diampu.

Pada jenjang pendidikan tinggi, terdapat sejumlah fungsi yang harus ditampilkan oleh perpustakaan sebagai implikasi penyelenggaraan tri dharma perguruan tinggi. Menurut Caster dan Bonk (dalam Noerhayati, 1999) fungsi tersebut meliputi:

(1). Mendukung kurikulum dengan bahan-bahan pustaka sesuai dengan subjek/materi pembelajaran di perguruan tinggi.

(2). Menyediakan koleksi yang ditujukan untuk pembinaan insan terdidik yang "humene", dan menyediakan bahan/koleksi untuk pengembangan profesi seperti penelitian. Sehubungan dengan itu, perlu dilakukan seleksi dan pengadaan bahan pustaka secara tepat dalam mendukung fungsi-fungsi tersebut.

Dalam dunia pendidikan, kehadiran perpustakaan dalam sebuah lembaga pendidikan bertujuan untuk menunjang pelaksanaan program pendidikan lembaga pendidikan di mana perpustakaan itu berada, melalui kegiatan menghimpun, mengolah dan penyebarluasan segala macam informasi edukatif atas dasar acuan kurikulum lembaga pendidikan tersebut. Di samping itu, menanamkan dan membina minat baca peserta didik, memperluas cakrawala pengetahuan adalah tujuan lain yang juga harus disasar oleh perpustakaan.

Seleksi dan pengadaan bahan pustaka secara tepat perlu dilakukan dalam mendukung fungsi-fungsi dan tujuan perpustakaan tersebut. Seleksi dan pemilihan koleksi yang tidak tepat akan menimbulkan kepincangan pada fungsi-fungsi sebagai akibat ketidakseimbangan bahan pustaka dan sumber lain yang harus diadakan. Akibatnya, mahasiswapun selaku pengguna tidak akan memperoleh manfaat yang optimal.

Terkait dengan hal tersebut di atas, terdapat sejumlah prinsip umum yang mesti diperhatikan oleh petugas perpustakaan dalam pelaksanaan pembinaan koleksi, antara lain:

(1) Prinsip relevansi

Koleksi perpustakaan harus relevan dengan program pendidikan, pengajaran, penelitian dan pengabdian masyarakat yang dilaksanakan semua unit di lingkungan perguruan tinggi bersangkutan.

(2) Prinsip Individualisasi

Pengadaan koleksi perlu mempertimbangkan kebutuhan individual pemakainya yang terdiri dari mahasiswa, dosen, peneliti, staf administrasi.

(3) Prinsip Kelengkapan

Di samping buku teks yang sesuai dengan kebutuhan perkuliahan, koleksi pustaka harus juga meliputi bidang ilmu lain yang sesuai dengan program pendidikan perguruan tinggi bersangkutan.

(4) Prinsip Kemutakhiran

Koleksi yang diadakan harus mempertimbangkan kemutakhiran sesuai perkembangan ilmu dan teknologi.

(5) Prinsip Kerjasama

Perlu kerjasama yang baik dengan semua pihak yang membutuhkan informasi agar programprogram perpustakaan berjalan dengan baik. 
Menurut Nuril Huda (1994), ada 5 unsur penting yang harus diperhatikan dalam pelayanan pengguna perpustakaan. Kelima unsur tersebut adalah: (1) materi layanan (bahan pustaka), (2) pelaksana layanan (staf), (3) metode layanan, (4) sarana pelayanan dan (5) pendukung pelayanan (termasuk kondisi/iklim kerja) perpustakaan. Implementasi kelima komponen tersebut harus dilakukan dengan memperhatikan faktor-faktor yang berpengaruh terhadap layanan yaitu: (1) karakteristik pengguna, (2) karakteristik pelaksana, (3) karakteristik lingkungan, termasuk di dalamnya adalah misi dan fungsi perguruan tinggi.

Hingga saat ini perpustakaan Undiksha selalu berupaya mempebaharui/menambah bahan pustaka untuk memenuhi kebutuhan dan meningkatkan kualitas layanan kepada pengguna. Dalam upaya memperbaharui dan menambah koleksi, Perpustakaan Undiksha selalu meminta masukan seperti daftar judul buku dari seluruh Jurusan di lingkungan Undiksha. Dengan demikian diharapkan buku-buku yang diadakan akan sesuai dengan tuntutan kurikulum Jurusan dan mampu meningkatkan kualitas pembelajaran. Diharapkan buku-buku yang diadakan akan sesuai dengan tuntutan kurikulum Jurusan dan mampu meningkatkan kualitas pembelajaran.

Di samping itu, kecukupan dan kenyamanan ruang baca juga sudah selayaknya dijadikan dasar pertimbangan penting dalam memberikan layanan yang memadai bagi pengguna. Efektivitas dan keramahan juga merupakan aspek penting yang harus termanifestasi dalam pelayanan bagi pengguna.

Dalam usaha pengembangan Undiksha ke depan khususnya ditingkat fakultas, perlu diupayakan kebijakan pengadaan bahan pustaka dan sistem layanan yang memadai yang mendorong para mahasiswa dan dosen di masing-masing fakultas memanfaatkan perpustakaan secara optimal, sebagi upaya dalam meningkatkan akreditasi jurusan yang tidak terlepas dari kinerja dan kemajuan fakultas. Muara akhirnya adalah menjadikan jurusan dan fakultas semakin maju.

Terkait dengan pengguna perpustakaan di lingkungan Fakultas Ilmu Pendidikan yang memiliki Jurusan PGSD terdiri dari 2 UPP yaitu UPP Singaraja dan UPP Denpasar, terdapat sejumlah permasalahan utamanya di Perpustakaan UPP Denpasar. Permasalahan yang dimaksud meliputi: tempat/ruang penyimpanan buku dan layanan pengguna termasuk representativitasnya, jumlah judul dan eksemplar buku, dan kekinian bahan pustakanya. Permasalahan lainnya adalah: dalam penulisan tugas akhir maupun skripsi mahasiswa cenderung menggunakan skripsi, makalah sejawat yang bukan referensi dari perpustakaan sebagai rujukan; menggunakan informasi dari internet dalam menyelesaikan berbagai tugas sehingga fungsi buku sebagai sumber infomasi rujukan cenderung tergeser termasuk dalam penggunaan bahan pustaka yang tersedia di perpustakaan; mahasiswa lebih memilih, hanya menggunakan buku yang ditulis oleh pengampu mata kuliah kendati perpustakaan telah menyiapkan bebagi sumber terkini yang bisa dipinjam, dipelajari untuk memperdalam dan memperluas wawasan. Hal ini perlu mendapat perhatian khusus mengingat UPP Denpasar sangat potensial menjadi sayap pengembangan ke depan bagi Undiksha pada umumnya dan khususnya bagi FIP.

Bertalian dengan itu maka dilakukan penelitian "Pemanfaatan Perpustakaan Undiksha dalam Menunjang Pembelajaran Mahasiswa Fakultas Ilmu Pendidikan”. Perpustakaan Undiksha yang dimaksud adalah Perpustakaan Undiksha yang ada di kampus Undiksha Singaraja dan perpustakaan yang ada di UPP Denpasar yang secara khusus bertugas memberikan layanan kepada mahasiswa dan dosen PGPAUD dan PGSD UPP Denpasar.

Penelitian ini bertujuan untuk: 1)Mendeskripsikan tingkat kunjungan mahasiswa FIP Undiksha ke Perpustakaan Undiksha; 2) Mendeskrisikan persepsi mahasiswa FIP Undiksha terhadap layanan pustakawan Perpustakaan Undiksha pada mahasiswa; Mendeskripsikan persepsi mahasiswa FIP Undiksha terhadap kesesuaian bahan pustaka di perpustakaan dengan kebutuhan pembelajaran (kesesuian dengan Mata Kuliah); Mendeskripsikan persepsi dosen FIP Undiksha terhadap kesesuaian bahan pustaka Perpustakaan Undiksha dengan kebutuhan pembelajaran (kurikulum jurusan); Mendeskripsikan faktor-faktor yang merupakan pendorong dan penghambat bagi para mahasiswa dan dosen dalam memanfaatkan Perpustakaan Undiksha.

\section{Metode Penelitian}

Penelitian ini adalah penelitian deskriptif yang mengkaji tentang pemanfaatan Perpustakaan Undiksha dalam menunjang pembelajaran mahasiswa Fakultas Ilmu Pendidikan. Penelitian ini dilakukan di Fakultas Ilmu Pendidikan dan di Perpustakaan Undiksha dengan variabel yaitu pemanfaatan Perpustakaan Undiksa dalam mendukung pembelajaran di FIP Undiksha yang dilihat dari sisi mahasiswa sebagai pengguna perpustakaan, pustakawan, koleksi pustaka dan dari sisi dosen.

Kajian dipusatkan pada beberapa aspek yang dipandang esensial dari variabel ini, yaitu: (1) Kunjungan mahasiswa ke perpustakaan, (2) persepsi/tanggapan mahasiswa terhadap layanan pustakawan, (3) kesesuaian bahan pustaka dengan kebutuhan pembelajaran/kurikulum jurusan di lingkungan FIP Undiksha dari sudut pandang mahasiswa, (4) kesesuaian bahan pustaka dengan kebutuhan pembelajaran/kurikulum 
jurusan di lingkungan FIP Undiksha dari sudut pandang dosen, (5) Pemanfaatan bahan pustaka oleh dosen,(6) Faktor pendorong dan penghambat penggunaan perpustakaan oleh mahasiswa dan dosen.

Subyek dalam penelitian ini adalah mahasiswa dan dosen di lingkungan FIP Undiksha. Mahasiswa sebagai subyek penelitian ini adalah mahasiswa di lingkungan FIP Undiksha yang berada di semua kelas di semester ganjil (semerter III dan V) tahun akademik 2016/2017 dan dosen di lingkungan FIP Undiksha. Penetapan subyek penelitian dilakukan dengan teknik kuwota proporsional random sampling berdasarkan total kelas pada semester bersangkutan.

Data dalam penelitian ini dikumpulkan dengan menggunakan metode angket, wawancara, pencatatan dokumen. Selanjutnya data penelitian dianalisis dengan menggunakan metode analisis deskriptif. Rumus statistik deskriptif yang digunakan dalam penelitian ini adalah sebagai berikut.

1. Rata-rata.

Keterangan:

$$
M=\frac{\sum f X}{\sum f}
$$

$\mathrm{M}=$ Rata-rata

$f=$ Frekuensi

$\mathrm{X}=$ Skor

Sumber: Koyan, 2009.

2 Pedoman PAP Skala Lima Rentang Persentil

\begin{tabular}{ccc}
\hline Rentang Skor & Kriteria & Klasifikasi \\
\hline $90 \%-100 \%$ & A & Sangat Baik \\
\hline $80 \%-89 \%$ & B & Baik \\
\hline $65 \%-79 \%$ & C & Cukup \\
\hline $40 \%-64 \%$ & D & Kurang Baik \\
\hline $0 \%-39 \%$ & E & Tidak Baik
\end{tabular}

Sumber: Diadaptasi dari Fernandes (1979)

\section{Hasil dan Pembahasan \\ Hasil Penelitian}

\section{Tingkat Kunjungan Mahasiswa FIP Undiksha ke Perpustakaan}

Tingkat kunjungan yang dicermati ini terbatas pada kunjungan mahasiswa FIP UPP Singaraja dan UPP Denpasar ke Perpustakaan, baik perpustakaan Undiksha yang ada di Singaraja maupun di UPP Denpasar di semester genap. Tingkat kunjungan mahasiswa tersebut dapat digambarkan sebagai berikut.

Tabel 1. Tigkat Kunjungan Mahasiswa FIP Undiksha ke Perpustakaan

\begin{tabular}{|c|c|c|c|c|c|c|c|}
\hline \multirow[t]{2}{*}{ No } & \multirow[t]{2}{*}{ Bulan } & \multicolumn{3}{|c|}{ Mahasiswa FIP Singaraja } & \multicolumn{3}{|c|}{ Mahasiswa FIP Denpasar } \\
\hline & & $\begin{array}{l}\text { Jml. } \\
\text { Mhs }\end{array}$ & $\begin{array}{l}\text { Pengun. / } \\
\text { peminj. } \\
\text { buku }\end{array}$ & $\%$ & $\begin{array}{l}\text { Jml. } \\
\text { Mhs. }\end{array}$ & $\begin{array}{c}\text { Peng. / } \\
\text { peminj. } \\
\text { buku }\end{array}$ & $\%$ \\
\hline 1 & Januari & \multirow[t]{6}{*}{1704 orang } & 175 & 10,3 & \multirow[t]{6}{*}{750 orang } & 82 & 10,9 \\
\hline 2 & Pebruari & & 381 & 22,4 & & 196 & 26,1 \\
\hline 3 & Maret & & 702 & 41,2 & & 288 & 38,4 \\
\hline 4 & April & & 549 & 32,2 & & 223 & 29,7 \\
\hline 5 & Mei & & 605 & 35,5 & & 211 & 28,1 \\
\hline 6 & Juni & & 503 & 29,5 & & 99 & 13,2 \\
\hline
\end{tabular}


Dengan menggunakan pertimbangan hari efektif pada bulan-bulan bersangkutan maka jumlah pengguna Perpustakaan Undiksha oleh mahasiswa FIP dapat dilihat pada tabel berikut.

Tabel 2. Rata-Rata Jumlah Pengguna Perpustakaan Undiksha per Hari oleh Mahasiswa FIP

\begin{tabular}{|c|c|c|c|c|c|c|c|}
\hline \multirow[t]{2}{*}{ No } & \multirow[t]{2}{*}{ Bulan } & \multicolumn{3}{|c|}{ Mahasiswa FIP Singaraja } & \multicolumn{3}{|c|}{ Mahasiswa FIP UPP Denpasar } \\
\hline & & $\begin{array}{l}\text { Jml. } \\
\text { Mhs. }\end{array}$ & $\begin{array}{c}\text { Pengg. } \\
\text { /hari efektif } \\
(\text { Org })\end{array}$ & $\%$ & $\begin{array}{l}\text { Jml. } \\
\text { Mhs. }\end{array}$ & $\begin{array}{c}\text { Pengg. } \\
\text { /hari efektif } \\
(\text { Org })\end{array}$ & $\%$ \\
\hline 1 & Januari & \multirow[t]{6}{*}{1704} & 9 & 0,5 & \multirow[t]{7}{*}{750} & 4 & 0.5 \\
\hline 2 & Pebruari & & 24 & 1.4 & & 12 & 1.6 \\
\hline 3 & Maret & & 35 & 2.0 & & 14 & 1.9 \\
\hline 4 & April & & 26 & 1.5 & & 11 & 1.5 \\
\hline 5 & Mei & & 30 & 1.8 & & 11 & 1.5 \\
\hline 6 & Juni & & 23 & 1.3 & & 5 & 0.6 \\
\hline & Rata-rata & & 25 & 1.42 & & 10 & 1.27 \\
\hline
\end{tabular}

Angka pengguna perpustakaan Undiksha sesuai tabel di atas menunjukkan bahwa tingkat pengguna perpustakaan Undikha oleh mahasiswa FIP di Singaraja maupun di Denpasar tergolong sangat kecil (Singaraja: $1.42 \%$ dan Denpasar: $1.27 \%$ ).

\section{Persepsi Mahasiswa Terhadap Pelayanan Perpustakaan}

secara umum persentase rerata skor persepsi mahasiswa di UPP Denpasar maupun Singaraja terhadap pelayanan pustakawan adalah $73.6 \%$ (cukup baik). Lebih lanjut, bila dibedakan persepsi mahasiswa FIP Singaraja dan mahahasiswa FIP UPP Denpasar maka rerata yang diperoleh adalah sebagai berikut. Persepsi mahasiswa FIP Singaraja terhadap pelayanan perpustakaan di Singaraja adalah 79,3\% (cukup baik). Rerata persen skor persepsi mahasiswa FIP UPP Denpasar adalah 60.5\% (kurang baik). Jika dibandingkan maka rerata persentase mahasiswa FIP Singaraja lebih besar $18.8 \%$ dibandingkan dengan mahasiswa FIP Singaraja.

\section{Persepsi Mahasiswa terhadap Kesesuaian Bahan Pustaka dalam Mendukung Perkuliahan}

Secara keseluruhan, Rerata persen persepsi/tanggapan mahasiswa FIP terhadap kesesuaian bahan pustaka dengan kebutuhan mahasiswa dalam mendukung perkuliahan di masing-masing jurusan adalah $71,1 \%$ (cukup baik). Rerata persen persepsi mahasiswa UPP Denpasar sebesar 60.5\% (kurang baik) ssedangkan mahasiswa FIP Singaraja sebesar 75.7\% (cukup baik). Rerata persepsi mahasiswa FIP Singaraja lebih besar $15.2 \%$ dibandingkan mahasiswa UPP Denpasar. Hal ini menandakan bahwa buku-buku/bahan pustaka yang ada di Perpustakaan Undiksha Singaraja lebih memadai dalam mendukung perkuliahan dibandingkan dengan bahan-bahan pustaka yang ada di perpustakaan UPP Denpasar.

\section{Persepsi Dosen terhadap Kesesuaian Bahan Pustaka Perpustakaan Undiksha dengan Kurikulum Jurusan}

Secara keseluruhan, persepsi/penilaian dosen FIP Undiksha (dosen FIP singaraja maupun FIP UPP Denpasar) terhadap kesesuaian bahan pustaka di Perpustakaan Undiksha dengan kurikulum jurusan tergolong cukup baik dengan rerata persen sebesar 71,1 \%. Persepsi dosen terhadap kesesuaian bahan pustaka perpustakaan Undiksha di Singaraja dengan kurikulum di masing-masing jurusan tergolong cukup baik (rerata persen: 74,2\%). Pandangan dosen FIP UPP Denpasar kesesuaian bahan pustaka dengan kurikulum jurusan tergolong kurang baik (rerata persen: 61,6\%). Terdapat perbedaan rerata skor sebesar $12,6 \%$ yang menandakan bahan pustaka di perpustakaan Undiksha di Singaraja lebih lengkap, lebih memadai dalam mendukung implementasi kurikulum jurusan.

\section{Faktor Pendorong dan Penghambat Kunjungan Mahasiswa dan Dosen ke Perpustakaan}

a. $\quad$ Fator Pendorong bagi Mahasiswa

Faktor pendorong bagi mahasiswa FIP Singaraja untuk mengunjungi perpustakaan adalah sebagai berikut. 1) penyelesaian tugas $(54.9 \%)$, 2) faktor niat mengembangkan wawasan $(45 \%)$, 3) faktor keterbatasan bahan bacaan yang dimiliki mahasiswa $(37.2 \%)$, 4) memperkaya materi kuliah $(36.7 \%), 5)$ kenyamanan dalam membaca di perpustakaan $(27.0 \%), 6)$ punya waktu yang cukup $(20.4 \%)$, 7) pelayanan pustakawan yang memadai $(19.9 \%)$ dan , 8) faktor ketersediaan bahan pustaka di perpustakaan $(18.1 \%)$. 
Berbeda dengan mahasiswa FIP UPP Singaraja, urutan faktor pendorong bagi mahasiswa di UPP Denpasar dalam mengunjungi perpustakaan adalah: 1) faktor penyelesaian tugas-tugas perkuliahan dan memperkaya materi kuliah $(76.0 \%)$, 2) niat mengembangkan wawasan $(57.3), 3)$ keterbatasan bahan bacaan yang dimiliki mahasiswa $(52.1 \%)$, 4) Punya cukup waktu $(28.1 \%)$, 5) kenyamanan dalam membaca di perpustakaan $(24.0 \%), 6)$ pelayanan pustakawan yang memadai $(12.5 \%)$ dan, 7) ketersediaan bahan pustaka di perpustakaan $(6.3 \%)$.

b. $\quad$ Faktor Penghambat bagi Mahasiswa

Urutan faktor penghambat bagi mahasiswa FIP Undiskha Singaraja mengunjungi perpustakaan adalah sebagai berikut, 1) banyaknya tugas perkuliahan $(32 \%)$, 2) enggan membaca $(30.1 \%), 3)$ materi belajar lebih mudah diperoleh di internet $(24.3 \%)$, 4) sudah ada buku pegangan dari dosen $(19 \%), 5)$ pelayanan pustakawan kurang memadai $(17.7 \%)$, 6) enggan berkunjung ke perustakaan $(16.8 \%)$, 7) bukubuku di pustakawan kurang memadai (15.9\%) dan, 8) tidak paham cara penelusuran buku (13.3\%).

Selanjutnya, urutan faktor penghambat mahasiswa FIP UPP Denpasar mengunjungi perpustakaan adalah sebagai berikut. 1) Buku perpustakaan kurang memadai (45.8\%), Materi belajar lebih mudah diperoleh dari internet $(44.8 \%), 3)$ enggan membaca $(43.8 \%)$, 4) enggan berkunjung ke perustakaan $(39.6 \%)$, 5) banyaknya tugas perkuliahan $(38.5 \%), 6$ ) tidak paham cara penelusuran buku $(31.3 \%)$, 7) sudah ada buku pegangan dari dosen pengajar $(28.1 \%), 8)$ pelayanan pustakawan kurang memadai $(26 \%)$.

\section{c. $\quad$ Fator Pendorong bagi Dosen}

Faktor pendorong bagi para dosen FIP di Singaraja dalam mengunjungi perpustakaan adalah sebagai berikut. 1) Meningkatkan kualitas materi kuliah (80\%), 2) Niat mengembangkan diri (56\%), 3) Keterbatasan bahan bacaan dosen (52\%), 4) Punya waktu luang yang cukup (24\%), 5) Koleksi perpustakaan yang memadai (16\%), 6) Layanan pustakawan yang mamadai (12\%), 7) sistem layanan perpustakaan yang memadai $(8 \%)$.

Faktor pendorong bagi para dosen FIP di UPP Denpasar adalah sebagai berikut. 1) Meningkatkan kualitas materi kuliah (75\%), 2) Niat mengembangkan diri (62.5\%), 3) Punya waktu luang yang cukup $(50 \%), 4)$ Keterbatasan bahan bacaan dosen $(37.5 \%)$, 5) Koleksi perpustakaan yang memadai $(25 \%), 6)$ Layanan pustakawan yang mamadai $(25 \%), 7)$ sistem layanan perpustakaan yang memadai $(25 \%)$.

\section{d. $\quad$ Faktor Penghambat bagi Dosen}

Faktor penghambat para dosen FIP Undiksha Singaraja berkunjung ke perpustakaan adalah sebagai berikut. 1) banyaknya tugas dosen $(76 \%), 2)$ bahan ajar terkini lebih mudah diperoleh dari internet $(56.0 \%)$, 3) keterbatasan waktu ke perpustakaan (40\%) 4) enggan membaca (20\%), 5) telah memiliki buku sumber yang memadai (20\%), 6) bahan pustaka perpustakaan kurang memadai (16\%), 7) layanan pustakawan kurang memadai $(8 \%), 8)$ tidak paham cara penelusuran buku $(4 \%), 9)$ sistem layanan perpustakaan kurnag memadai $(0 \%)$.

Sedangkan, berdasarkan data yang diperoleh dari, faktor penghambat dosen-dosen FIP UPP Denpasar berkunjung ke perpustakaan berturut-turut adalah sebagai berikut. 1) banyaknya tugas dosen $(62.5 \%)$, 2) bahan ajar terkini lebih mudah diperoleh dari internet $(50 \%)$, 3) keterbatasan waktu ke perpustakaan $(37.5 \%)$, 4) telah memiliki buku sumber yang memadai (12.5\%), 5) bahan pustaka perpustakaan kurang memadai $(12.5 \%)$, 6) tidak paham cara penelusuran buku (12.5\%), 7) layanan perpustakaan kurnag memadai $(0 \%)$.

\section{Pembahasan}

Secara umum perpustakaan Undiksha telah berupaya melakukan layanan optimal. Optimalisasi usaha pelayanan itu dilakukan dengan memperbaiki sistem layanan, pendidikan pelatihan bagi pustakawan, pembuatan pedoman pengguna perpustakaan, pengadaan buku, penerapan fungsi. Penambahan berbagai fasilitas yang dibutuhkan dalam memberikan layanan, mensosialisasikan pedoman dan teknis penelusuran bahan pustaka bagi mahasiswa baru termasuk kewajiban bagi mahasiswa untuk menjadi anggota perpustakaan. Namun melalui penelitian ini dapat diungkap hal-hal sebagai berikut.

Pemanfaatan bahan pustaka oleh mahasiswa masih belum optimal, khususnya dikalangan mahasiswa FIP Undiksha. Hal itu dapat dilihat dari rata-rata kunjungan dan peminjaman buku oleh mahasiswa FIP di Singaraja hanyalah 25 orang dari seluruh mahasiswa Singaraja yang berjumlah 1704 orang $(1,42 \%)$ per hari efektif pada rentang bulan Januari sampai dengan bulan Juni. Sementara itu, pengguna atau peminjaman buku oleh mahasiswa UPP Denpasar hanya 10 orang per hari efektif dari 750 orang mahasiswa FIP di UPP Denpasar (1,27\%). Ini adalah jumlah yang sangat kecil jika dilihat dari jumlah seluruh mahasiswa FIP baik di Denpasar maupun di Singaraja. Adapun kunjungan mahasiswa ke perpustakaan pada prosentase tertinggi berada pada bulan Maret, April dan Mei. Hal itu terjadi karena pada bulan-bulan tersebut tugas perkuliahan yang harus diselesaikan oleh mahasiswa relatif banyak, yang mendorong mahasiswa harus menggunakan bahan pustaka yang ada di perpustakaan. 
Rendahnya tingkat kunjungan mahasiswa keperpustakaan dapat merupakan akibat dari hal-hal sebagai berikut.

a. Terbatasnya jumlah buku yang tersedia di perpustakaan.

b. Kurang memadainya judul dan eksemplar buku yang sesuai dengan kebutuhan perkuliahan.

c. Bahan yang dibutuhkan mahasiswa untuk perkuliahan dan pembuatan tugas lebih mudah diperoleh melalui internet.

d. Kecilnya minat baca di kalangan mahasiswa sebagaimana terungkap melalui angket. Sejumlah mahasiswa enggan berkunjung ke perpustakaan.

Pada aspek layanan pustakawan ditengarai bahwa secara umum layanan pustakawan tergolong cukup baik (rerata: 73.6\%). Namun bila dipilah, nampak bahwa layanan pustakawan di perpustakaan Undiksha di Singaraja tergolong cukup baik (rerata: 79.3\%) sedangkan di kampus UPP Denpasar masih kurang baik (rerata: $60.5 \%$ ). Hal ini menandakan bahwa pelayanan pustakawan masih perlu dioptimalkan baik di UPP di Denpasar maupun di Singaraja. Mengingat perpustakaan sangat menentukan kualitas layanan pendidikan maka pustakawan sebagai ujung tombak pelayanan mesti meningkatkan kualitasnya baik dari aspek komitmen pelayanan, semangat pelayanan termasuk aspek-aspek lain yang terkait dengan pelayanan harus lebih ditingkatkan.

Pada aspek kesesuaian bahan pustaka dengan kebutuhan mahasiswa dalam menunjang perkuliahan, secara umum mahasiswa memiliki persepsi cukup baik (rerata: 71.1\%). Bila dipilah antara mahasiswa FIP di Singaraja dengan mahasiswa FIP UPP Denpasar maka nampak bahwa mahasiswa UPP Denpasar memandang bahwa kesesuaian bahan pustaka di perpustakaan UPP Denpasar masih tergolong kurang memadai (kurang baik) (rerata: $60.5 \%$ ). Sementara itu kesesuaian bahan pustaka Perpustakaan di Singaraja tergolong cukup baik (rerata:75.7\%). Hal ini menandakan bahwa sistem pengadaan buku harus diperbaiki. Untuk itu para dosen pengampu mata kuliah di masing-masing jurusan perlu dilibatkan dalam pengadaan buku utamanya dalam mengidentifikasi judul buku (termasuk penulis buku dan penerbitnya) yang sesuai dengan tuntutan kurikulum. Dalam kaitan ini para dosenpun mesti aktif memberi masukan kepada pengelola perpustakaan dalam hal pengadaan buku agar buku-buku yang diadakan oleh perpustakaan representative dalam mendukung perkuliahan. Khususnya untuk kebutuhan mahasiswa jurusan PGSD FIP Undiksha, perlu diadakan buku-buku yang terikat dengan kebutuhan pembelajaran di SD. Buku-buku ini belum tersedia memadai di perpustakaan, baik di perpustakaan Undikha di Singaraja maupun perpustakaan di UPP Denpasar.

Sama halnya dengan persepsi mahasiswa terhdap kesesuaian bahan pustaka dengan kebutuhan perkuliahan, dosenpun memiliki persepsi yang sama terhadap kesesuaian bahan pustaka perpustakan dengan kurikulum jurusan. Secara umum persepsi dosen terhadap kesesuaian bahan pustaka di perpustakaan dengan kurikulum jurusan tergolong cukup baik dengan rerata persentase sebesar $71.1 \%$. Tingkat kesesuaian di Perpustakaan Singaraja tergolong cukup baik dengan rerata persentase sebesar $71.2 \%$ dan kesesuaian bahan pustaka di Perpustakaan UPP Denpasar tergolong kurang baik denan rerata persentase sebesar $61.6 \%$. Artinya, secara kuantitas dan kualitas, buku- buku di perpustakaan Undiksha di Singaraja masih lebih baik dibandingkan dengan buku-buku atau bahan pustaka di Perpustakaan UPP Denpasar. Pada intinya, hal ini dapat dijadikan rekomendasi bahwa pengadaan bahan pustaka perlu memperhatikan masukan dari para dosen pengampu mata kuliah di masing-masing jurusan seperti telah diuraikan di atas.

Dosen adalah salah satu bagian dari pengguna perpustakaan. Dari sisi dosen baik dosen FIP di Singaraja maupun di UPP Denpasar, aspek pendorong terkuat bagi pihak dosen untuk mengunjungi perpustakaan adalah meningkatkan kualitas materi kuliah (Singaraja (80\%), Denpasar (75\%)) yang disusul Niat mengembangkan diri (Singaraja (56\%) dan Denpasar (62.5\%)) serta Keterbatasan bahan bacaan dosen (52\%) sedangkan faktor terkecil yang mendorong dosen ke perpustakaan adalah sistem layanan perpustakaan yang memadai (Singaraja (8\%) dan Denpasar (25\%)).

Hal ini menandakan bahwa para dosen memiliki komitmen yang baik untuk senantiasa menyempurnakan materi perkuliahan yang didukung oleh komitmen untuk mengembangkan diri. Untuk mendukung hal tersebut, maka perpustakaan mesti senantiasa berupaya mengadakan bahan pustaka yang seirama dengan komitmen untuk menyempurnakan materi kuliah dan mengembangkan diri.

Sementara itu, walaupun ada hal yang medorong para dosen berkunjung ke perpustakaan namun para dosen juga memiliki hambatan-hambatan tertentu. Adapun hal-hal yang menjadi hambatan bagi para dosen untuk mengunjungi perpustakaan adalah sebagai berikut. Faktor penghambat terkuat bagi para dosen di lingkungan FIP Undiksha Singaraja maupun Dosen di lingkungan UPP Denpasar adalah banyaknya tugas dosen (Singaraja:76\% dan Denpasar: 62.5\% ) kemudian disusul oleh bahan ajar terkini lebih mudah diperoleh dari internet (Singaraja: 56.0\% dan Denpasar: 50\%) sedangkan faktor penghambat terkuat ke tiga adalah keterbatasan waktu ke perpustakaan (Singaraja : 40\% dan Denpasar: 37.5\%). Hal ini sangat dimungkinkan karena sebagian besar dosen FIP memegang tugas tambahan, mulai dari Kajur, Dekanat hingga rektor di samping bertugas di lembaga-lembaga tingkat Rektorat. Kesibukan yang dimiliki sesuai 
tuntutan tugas berimplikasi pada terbatasnya waktu yang mereka miliki untuk berkunjung ke perpustakaan. Namun demikian, buku-buku rujukan yang dimiliki dosen, tersedianya berbagai bahan dan materi pembelajaran yang tersaji di internet yang sangat mudah diakses, sangat membantu para dosen dalam mengembangkan materi kuliah termasuk tugas-tugas lainnya dalam keterbatasan waktu yang mereka miliki. Hal ini sekaligus merupakan petunjuk bahwa perlu dikembangkan sistem pelayanan perpustakaan online/berbasis internet yang memadai yang mengadopsi kemajuan teknologi masa kini.

Faktor penghambat terlemah bagi para dosen untuk mengunjungi perpustakaan adalah sistem layanan perpustakaan kurang memadai (Singaraja: 0\% dan Denpasar: 0\%). Hal ini menandakan bahwa sistem layanan yang ada diperpustakaan sudah memadai sehingga tidak menimbulkan hambatan bagi pengunjung/pengguna perpustakaan termasuk di kalangan dosen.

Terkait dengan pnggunaan bahan pustaka, perlu diperhatikan hal-hal sebagi berikut.

1. Dalam hal penggunan bahan belajar yang diakses dari internet, harus dihindari copy paste semata terutama dari sumber-sumber yang tidak terpercaya, dapat dipertanggungjawabkan secara akademis. Tidak semua bahan yang disajikan di internet layak digunakan oleh mahasiswa.

2. Dosen perlu mengidentifikasi bahan pustaka, rujukan yang ada diperpustakaan dan mendorong mahasiswa untuk menggunakannya dalam menyelesaikan tugas-tugas perkuliahan. Hal ini penting dilakukan untuk mendorong mahasiwa menggunakan bahan pustaka yang ada di perpustakaan sekaligus sebagai upaya untuk menumbuhkan minat baca di kalangan mahasiswa.

Sebagaimana terungkap melalui angket penambahan jumlah buku sesuai jumlah mahassiwa, kesesuaian bahan pustaka dengan kebutuhan kurikulum adalah hal mendasar yang mesti dilakukan untuk menarik minat mahasiswa mengunjungi perpustakaan. Khususnya di perpustakaan UPP Denpasar tergolong kurang memadai baik jumlah maupun jenis bukunya. Buku-buku/bahan pustaka yang ada diperpustakaan kebanyakan buku lama yaitu buku-buku peninggalan Program D2 PGSD. Hingga kini buku tersebut tetap dijadikan rujukan utama dalam perkuliahan di jenjang S1. Karena itu pengadaan buku yang sesuai dangan jumlah mahasiswa dan tuntutan kurikulum mesti segera dilakukan.

Untuk membantu mahasiswa dalam menyelesaikan tugas akhir, dibutuhkan skripsi/tesis dan jurnal ilmiah. Karena itu, skripsi, tesis dan jurnal ilmiah perlu disediakan diperpustakaan. Namun perlu diupayakan agar ketika mahasiswa menyelesaikan tugas akhir tidak terjadi duplikasi skripsi.

Layanan Pustakawan perlu ditingkatkan, kenyamanan ruang baca perlu termasuk kebersihan dan penataan buku parlu ditingkatkan, perlu disediakan akses internet yang memadai.

Terkait dengan peminjaman buku, perlu dipertegas desiplin peminjaman buku oleh dosen baik yang bertalian dengan lama peminjaman dan jumlah peminjaman. Para dosen perlu memiliki kartu anggota perpustakaan. Pola dan teknis peminjamannya pun sama seperti anggota perpustakaan lainnya. Perlu dihindari jumlah buku dan lamanya waktu peminjaman oleh dosen. Hal ini penting agar persediaan buku yang terbatas di perpustakaan bisa digunakan secara efisien.

\section{Simpulan dan Saran}

Berdasarkan analisis data diatas, dapat ditarik kesimpulan sebagai berikut.

1. Tingkat kunjungan mahasiswa FIP ke perpustakaan Undiksha tergolong sangat kecil.

2. Persepsi mahasiswa FIP Undiksha terhadap layanan perpustakaan secara umum tergolong cukup baik. Secara rinci, persepsi mahasiswa FIP Undiksha Singaraja tergolong cukup baik. Persepsi mahasiswa UPP Denpasar tergolong kurang baik.

3. Persepsi mahasiswa FIP Undiksha terhadap kesesuaian bahan pustaka dalam mendukung perkuliahan secara umum tergolong cukup baik. Secara rinci, persepsi mahasiswa FIP Undiksha Singaraja adalah cukup baik dan persepsi mahasiswa UPP Denpasar adalah kurang baik.

4. Tanggapan dosen FIP Undiksha terhadap kesesuaian bahan pustaka dengan kurikulum jurusan secara umum tergolong cukup baik. Secara rinci, persepsi dosen FIP Undiksha Singaraja cukup baik dan dosen UPP Denpasar kurang baik.

5. Faktor pendorong dan penghambat kunjungan dosen ke perpustakaan adalah sebagai berikut.

a. Faktor Pendorong

Faktor pendorong dosen di lingkungan FIP di Singaraja dalam mengunjungi perpustakaan adalah: 1) Meningkatkan kualitas materi kuliah (80\%), 2) Niat mengembangkan diri (56\%), 3) Keterbatasan bahan bacaan dosen (52\%), 4) Punya waktu luang yang cukup (24\%), 5) Koleksi perpustakaan yang memadai (16\%), 6) Layanan pustakawan yang mamadai (12\%), 7) sistem layanan perpustakaan yang memadai $(8 \%)$.

Faktor pendorong bagi para dosen FIP di UPP Denpasar adalah: 1) Meningkatkan kualitas materi kuliah (75\%), 2) Niat mengembangkan diri (62.5\%), 3) Punya waktu luang yang cukup (50\%), 4) Keterbatasan bahan bacaan dosen $(37.5 \%)$, 5) Koleksi perpustakaan yang memadai $(25 \%), 6)$ Layanan pustakawan yang mamadai $(25 \%), 7)$ sistem layanan perpustakaan yang memadai $(25 \%)$. 


\section{b. Faktor Penghambat}

Faktor penghambat para dosen di lingkungan FIP Undiksha Singaraja adalah: 1) Banyaknya tugas dosen (76\%) 2) Bahan ajar terkini lebih mudah diperoleh dari internet (56.0\%) 3) Keterbatasan waktu ke perpustakaan (40\%) 4) Enggan membaca (20\%), 5) Telah memiliki buku sumber yang memadai (20\%), 6) Bahan pustaka perpustakaan kurang memadai (16\%), 7) Layanan pustakawan kurang memadai (8\%), 8) Tidak paham cara penelusuran buku (4\%), 9) Sistem layanan perpustakaan kurang memadai $(0 \%)$.

Sedangkan faktor penghambat dosen FIP UPP Denpasar adalah 1) Banyaknya tugas dosen (62.5\%), 2) Bahan ajar terkini lebih mudah diperoleh dari internet (50\%), 3) Keterbatasan waktu ke perpustakaan $(37.5 \%)$, 4) Telah memiliki buku sumber yang memadai (12.5\%), 5) Bahan pustaka perpustakaan kurang memadai $(12.5 \%)$, 6) Tidak paham cara penelusuran buku $(12.5 \%), 7)$ Layanan pustakawan kurang memadai (12.5\%), 8) Enggan membaca (12.5\%), 9) Sistem layanan perpustakaan kurang memadai $(0 \%)$.

\section{Daftar Pustaka}

Agung, A.A. Gede. 2014. Buku Ajar Metode Penelitian Pendidikan.Malang: Aditya Media Publising.

Artinah. 1991. Pelayanan Pemakaian dan Kerjasama Antar Perpustakaan Perguruan Tinggi. Jakarta : Ditjen Dikti

Basuki, Sulistyo. 1993. Pengantar Ilmu Perpustakaan. Jakrta : PT Gramedia Pustaka Utama

Gretes, Frances. 2013. School Library Impact Studies: A Review of Findings and Guide to Sources.

Huda, H. Nuril. 1999. Manajemen Pelayanan Pengguna Perpustakaan. Jakarta : Ditjen Dikti

Hamakonda, Towa. P. 1987. Pembinaan Koleksi Perpustakaan Perguruan Tinggi. Jakarta : Ditjen Dikti

Indris Suryana, Moh. 1994. Manajemen Staf Perpustakaan Perguruan Tinggi. Jakarta : Ditjen Dikti

Jasmani. 1985. Beberapa Pendekatan Alternatif ke Arah Profesionalisme Pustakawan, dalam Bunga Rampai Perpustakaan. Bandung : IKIP

Kartosedono, Soekarman dan Zulfikar Zen. 1994. Peranan Perpustakaan Anak-anak/Sekolah dalam Meningkatkan Mutu Pendidikan. Jakarta: Ditjen Dikti

Mangnga, A. 2015. Peran Perpustakaan Sekolah Terhadap Proses Belajar Mengajar di Sekolah. Jupiter. Vol. XIV (No.1)

Martono, E. 1991. Pengetahuan Dokumentasi dan Perpustakaan sebagai Pusat Informasi. Jakrta : Karya Utama

Mary Duncan, Carter dan Walace John Bonk. 1959. Building Library Collection. New York : Scarecrow

Nurhayati S. 1989. Pengelolaan Perpustakaan. Jakarta : Percetakan Alumni

Presiden Republik Indonesia. 2003. Undang-Undang No 20 Tahun 2003 tentang Sistem Pendidikan Nasional. Jakarta

Siregar, A. R. 2006. Perpustakaan: Energi Pembangunan Bangsa. Tersedia pada repository.usu.ac.id/bitstream/123456789/1682/1/979-458-206-9.pdf(diakses: 13/6/2016)

Soeatminah. 1992. Perpustakaan, Kepustakawanan, dan Pustakawan. Yogyakarta : Kanisius

Sudiono, Anas. 1977.Pengantar Statistik Pendidikan. Jakarta : PT Raja Grafindo Persada

Sumardji, P. 1995. Perpustakaan : Organisasi dan Tata Kerjanya. Yagyakarta : Kanisius

Surachman, A. tt. Manajemen Perpustakaan Sekolah. Jogjakarta: Universitas Gajah Mada.

Tood, R. J., Gordon, C. A. \& Gaver, M. 2012. School Libraries, Now More Than Ever: A Position Paper of The Center for International Scholarship in School Libraries. The Center for International Scholarship in School Libraries. Tersedia pada http://njasl.info/wp-content/NJ_study/Oct2012_ CISSL.pdf (diakses: 13/6/2016)

Undiksha. 2015. Buku Panduan Penggunaan Perpustakaan Universitas Pendidikan Ganesha. Singaraja: Undiksha 